International Journal of Biology, Pharmacy and Allied Seiences (IJBPAS)

'A Bridge Betueen Caboratory and QRendo'

WwW.iibpas.com

\title{
SOIL PROFILE OF VINOBA BHAVE UNIVERSITY CAMPUS
}

\author{
MISHRA PK* AND RANJAN A \\ Department Of Botany, Vinoba Bhave University, Hazaribag-825319 \\ *Corresponding Author: E Mail- pkm.vbu@gmail.com; Mob - 8986823937
}

Received $29^{\text {th }}$ July 2019; Revised $26^{\text {th }}$ Aug. 2019; Accepted $28^{\text {th }}$ Sept. 2019; Available online $1^{\text {st }}$ Jan. 2020

https://doi.org/10.31032/IJBPAS/2020/9.1.4921

\begin{abstract}
University campus is hub of activities and is known for its dynamism. To know and properly manage various environmental activities is important therefore. Edaphic factors are important to maintain vegetation of any area and keeping this fact in mind present study was conceived to evaluate soil characteristics of Vinoba Bhave University campus. In ten different stations randomly selected, marked variation in $\mathrm{pH}$ and electric conductivity was observed. Macronutrient and micro nutrient compositions of soil sample also varied considerably. This variation may be because of manipulations done from time to time depending upon land use pattern.
\end{abstract}

Keywords: University, Soil profile, Electric conductivity, pH, Nutrients

\section{INTRODUCTION}

Vinoba Bhave University campus is spread in 67.8 acre area and it caters educational need of North Chhotanagpur area of Jharkhand. Thousands of students spent fairly long hour of day in the campus hence, the area is a site of various activities. Responsibility of University does not confine to just teaching learning and research but it is torch bearer of society and it has to address various social issues as well. It is undisputed that environmental concern is primary social as well as scientific issue and keeping this fact in mind soil characteristic of Vinoba Bhave University campus was studied. Soil characteristics are a basic input for proper land management and it also help us in formulating strategies for plantation in the campus. Several workers like [1-3]. This is however a maiden attempt to study soil characteristic of Vinoba Bhave University campus. 


\section{MATERIAL AND METHODS}

Soil sample were collected from ten stations around different localities of Vinoba Bhave University. Monolith was dug and soil sample were collected from twenty centimetres uniform depth, collected in polythene bag and brought in laboratory. Soil sample was air dried and physic chemical analysis was done following standard methods. $\mathrm{pH}$, Organic Carbon, available macronutrient were estimated following method suggested by [4]. Nitrogen was estimated following methods of [5]. Fe, Mn., $\mathrm{Zn}$. and $\mathrm{Cu}$ was estimated by methods of [6].

\section{RESULTS AND DISCUSSION}

All together soil samples were collected from ten sampling sites of Vinoba Bhave University campus. $\mathrm{pH}$ of soil ranged from 5.40 to 8.02 . Lowest $\mathrm{pH}$ was recorded in sample collected from football ground where as highest $\mathrm{Ph}$. Was recorded in sample collected from back side of Bank of India. Soil samples collected from other stations were having $\mathrm{pH}$ above 7.0 and below 8.0. Another noteworthy parameter analysed was organic carbon. Minimum organic carbon was recorded in sample collected from UCET Workshop and the value was 0.20 . Highest organic carbon was found in sample collected from garden in front of Arts block and the value was 0.72. Lowest value of available Nitrogen was estimated in sample collected in front of UCET Workshop and the value was $95 \mathrm{~kg} / \mathrm{ha}$. Highest value of available Nitrogen was recorded in sample collected from Guest house premises and the value was $301 \mathrm{~kg} / \mathrm{ha}$. Lowest available sulphur was found in sample collected from premises of Botany department where as highest value was found in sample collected from Central Library premises and the value was 8.04. Lowest value of available Potassium was $161.2 \mathrm{~kg} / \mathrm{ha}$ from sample collected from Botanical garden. Highest value of available Potassium was $435.68 \mathrm{~kg} / \mathrm{ha}$ and was recorded in sample from football ground. Value of electric conductivity ranged from 0.03 Siemens/meter and was calculated in sample from Botanical garden and Central library to 0.11 Siemens/meter and was recorded in samples from UCET Workshop and arts block garden. Lowest value for copper, $0.704 \mathrm{ppm}$ was recorded from sample collected from UCET work shop and Botanical garden. Highest copper was found in soil collected from Science block building and the value was $2.24 \mathrm{ppm}$. Iron is another noteworthy mineral of soil which decides productivity of soil. Highest value of this mineral was $27.56 \mathrm{ppm}$ and the lowest value was $6.67 \mathrm{ppm}$ recorded from arts building garden. Zinc content in soil of Vinoba Bhave University campus ranged from $0.42 \mathrm{ppm}$ to $1.272 \mathrm{ppm}$ recorded from 
Botany department site and Central library site respectively. Highest Manganese content was $46.48 \mathrm{ppm}$ recorded from sample collected from football ground where as lowest value was from sample collected from sample collected from guest house and the value was $9.52 \mathrm{ppm}$ (Table 1).

Different soil parameters have significant affect on soil characteristic and it directly impact soil plant relationship. It also provides an important input for proper land use. Availability of nutrients as well as acidity/alkalinity is determined by soil $\mathrm{pH}$. Exchange of cation and water relation is also an active process and depends upon $\mathrm{pH}$ of soil. Similarly different macro nutrients and micro nutrients play vital role in plant growth. Results obtained during this study clearly indicate drastic variation in soil characteristics of Vinoba Bhave University. Apart from variation in topography, various amendments done from time to time depending upon requirement and campus planning may be the possible reason.

Table 1: Soil Characteristic Of Vbu Campus

\begin{tabular}{|c|c|c|c|c|c|c|c|c|c|c|c|}
\hline $\begin{array}{c}\text { S. } \\
\text { No. }\end{array}$ & Site & pH & $\begin{array}{c}\text { Organic } \\
\text { carbon } \\
(\%) \\
\end{array}$ & $\begin{array}{c}\text { Available } \\
\text { nitrogen } \\
(\mathrm{kg} / \mathrm{h})\end{array}$ & $\begin{array}{c}\text { Available } \\
\text { sulphur } \\
\text { (kg/h) }\end{array}$ & $\begin{array}{c}\text { Available } \\
\text { potassium } \\
(\mathrm{kg} / \mathrm{h})\end{array}$ & EC & $\begin{array}{c}\mathrm{Cu} \\
(\mathrm{ppm})\end{array}$ & $\begin{array}{c}\mathrm{Fe} \\
(\mathrm{ppm})\end{array}$ & $\begin{array}{c}\mathrm{Zn} \\
(\mathbf{p p m})\end{array}$ & $\begin{array}{c}\text { Mn } \\
(\mathrm{ppm})\end{array}$ \\
\hline 1 & Football ground & 5.40 & 0.44 & 198 & 4.86 & 435.68 & 0.04 & 0.8 & 27.56 & 1.2 & 46.48 \\
\hline 2 & $\begin{array}{c}\text { Front of UCET } \\
\text { Workshop }\end{array}$ & 7.60 & 0.20 & 95 & 3.60 & 282.24 & 0.11 & 0.704 & 12.77 & 0.928 & 17.98 \\
\hline 3 & $\begin{array}{l}\text { Sarojini Nayadu } \\
\text { Girl's Hostel }\end{array}$ & 7.83 & 0.35 & 166.25 & 6.98 & 178.08 & 0.06 & 0.909 & 15.82 & 1.064 & 20.36 \\
\hline 4 & $\begin{array}{l}\text { Back of Science } \\
\text { Block } 1\end{array}$ & 7.54 & 0.50 & 200 & 6.35 & 247.52 & 0.04 & 2.24 & 13.64 & 1.108 & 41.16 \\
\hline 5 & $\begin{array}{l}\text { Arts Block } \\
\text { Garden }\end{array}$ & 7.90 & 0.72 & 270 & 5.29 & 284.48 & 0.11 & 0.896 & 6.67 & 0.86 & 20.12 \\
\hline 6 & $\begin{array}{c}\text { Back of Central } \\
\text { Library }\end{array}$ & 8.02 & 0.26 & 123.5 & 8.04 & 411.04 & 0.03 & 0.848 & 7.77 & 1.712 & 30.38 \\
\hline 7 & $\begin{array}{l}\text { Right side of } \\
\text { Botany Deptt. }\end{array}$ & 7.47 & 0.24 & 124 & 2.54 & 232.96 & 0.04 & 0.704 & 11.03 & 0.42 & 10.23 \\
\hline 8 & Botanical Garden & 7.47 & 0.41 & 184.5 & 3.17 & 161.28 & 0.03 & 0.848 & 8.36 & 1.02 & 32.46 \\
\hline 9 & Guest House & 7.88 & 0.86 & 301 & 5.71 & 263.2 & 0.11 & 1.136 & 26.25 & 1.272 & 9.52 \\
\hline 10 & $\begin{array}{c}\text { Vivekanand } \\
\text { Sabhagar }\end{array}$ & 7.52 & 0.29 & 137.75 & 5.08 & 240.8 & 0.06 & 1.088 & 14.08 & 0.928 & 26.03 \\
\hline
\end{tabular}

\section{CONCLUSION}

It is concluded from the results obtained during this study that soil is a very dynamic ecological factor and it varies significantly from place to place. Soil characteristics and land use pattern is intrinsically related to each other and has got profound impact on other. It is also concluded that if proper soil amendment is done, soil can be used for various purposes.

\section{REFERENCES}

[1] Swati A Jain, MS Jagtap and KP Patel (2914). Physico chemical character of soil of Lunawada Tehsil, Distt. Mahisagar, Gujrat. Indian Journal of Scientific and 
Industrial Publication. 4 (3), 110 115.

[2] Sonika Jha and Sunitha V (2015). Nutrient analysis of soil sample from variety of places. Journal of Chemical and Pharmaceutical research. 7(3), $291-293$.

[3] Chandak Nisha, Maity Barnali and Kamlesh Shah (2017), Analysis of soil samples for its Physicochemucal parameters from Kadi city. Newest International Refereed Journal. 4(3), 36 - 40.

[4] Page, A.L., Miller, R.H and Keeney, D.R. (1982) Methods of Soil Analysis, Pat - 2, Chemical and Biological Properties, Soil Sc. Soc. Am. Soc. Agron. Madison, Washihgton, USA.

[5] Subbaiah, B. V. and Asija, G. L. (1956). A rapid procedure for determination of available Nitrogen in soil. Current Science, 25, 259 260.

[6] Lindsay, W. L. and Norvell, W.A. (1978). Development of a DTPA micronutrients soil test for $\mathrm{Zn}, \mathrm{Fe}$, $\mathrm{Mn}$ and Cu. Soil Sci. Soil. Am. Proceedings. 42, 421 - 428. 